\title{
Apresentação
}

\section{Pedagogia, inovação pedagógica e o papel que devem ter nos estudos curriculares}

Carlos Nogueira Fino*

William Pinar, num artigo intitulado The Problem with Curriculum and Pedagogy, defende que o estudo (study), que se baseia na individualidade, na autonomia e na criatividade, e se distingue de ensino (teaching), de instrução (instruction) e de pedagogia (pedagogy), merece o estatuto de conceito subsidiário dos estudos curriculares.

Nesse artigo, Pinar considera ter sido um erro histórico a criação, em 1938, do primeiro Department of Curriculum and Teaching, no Teachers College da Universidade de Colúmbia, porque, na sua opinião, a combinação de currículo e ensino fez expandir o papel do professor.

Refira-se que educação, tanto nessa época, como na atual, era fortemente marcada pela influência da engenharia social, a qual se manifestava na busca da maior eficiência, que se alcançaria através da melhor técnica, das melhores práticas, dos melhores standards. Entenda-se, também, que a engenharia social da instrução, ao reduzir o papel dos alunos à subalternidade, abria o caminho para a responsabilização dos professores pelos resultados obtidos pelos seus discentes, que só poderiam ser a consequência direta do trabalho e da competência dos docentes, no exercício das suas funções de engenheiros das sequências de ensino-aprendizagem.

Mas, acontece que Pinar também deteta, no seu texto, uma inflação do papel dos professores adeptos da edu-

* Professor Catedrático (Full Professor). Presidente da Faculdade de Ciências Sociais e responsável pela linha de pesquisa em inovação pedagógica do Centro de Investigação em Educação (CIE-UMa) da Universidade da Madeira, Portugal.cfino@staff.uma.pt 
cação progressiva, reclamando a necessidade de ajustar o estatuto inflacionado que a pedagogia terá no âmbito dos estudos curriculares:

Despite its very different politics, progressive education also inflated the role of the teacher in the process of education, suggesting that role could be socially transformative.

Adjusting the inflated status of pedagogy in curriculum studies will be difficult but necessary labor. (PINAR, 2005, p. 2)

Se, por um lado, tendo a acompanhar o entusiasmo pelo study, por compreender que ele, fundando-se na individualidade, na autonomia e na criatividade de quem estuda, está ao seu serviço e questiona, implicitamente, a própria existência de um currículo a priori, por outro, tenho dificuldade em lidar com uma conceção "desinflacionada" de pedagogia, que a reduza a pouco mais que um conjunto de procedimentos didáticos, exercidos no microcosmos da sala de aula.

E, quando penso num significado para a palavra pedagogia, tão extenso e complexo como o que Ihe é conferido por Paulo Freire, na Pedagogia do Oprimido, por exemplo, sou levado a considerar que, longe de estar exorbitado, se me afigura mínimo o estatuto que a pedagogia tem, atualmente, nos estudos curriculares.

De facto, pensar pedagogia como ação dialógica, que envolve educandos e educadores, e que começa muito antes e termina muito depois do "ato pedagógico"

A pedagogia do oprimido, como pedagogia humanista e libertadora, terá dois momentos distintos. O primeiro, em que os oprimidos vão desvelando o mundo da opressão e vão comprometendo-se na práxis, com a sua transformação; o segundo, em que, transformada a realidade opressora, esta pedagogia deixa de ser do oprimido e passa a ser a pedagogia dos homens em processo de permanente libertação (FREIRE, 2010, p. 46).

e colocar a questão da construção do conhecimento pelos educandos superando a doxa
Pelo fato mesmo de esta prática educativa constituir-se em uma situação gnosiológica, o papel do educador problematizador é proporcionar, com os educandos, as condições em que se dê a superação do conhecimento no nível da "doxa" pelo verdadeiro conhecimento, o que se dá, no nível do "logos". (FREIRE, 2010, p. 80)

remetem para uma conceção de pedagogia que extravasa da sala de aula para o mundo, como lugar onde se vive, e onde aprender é parte intrínseca da vida, elevando-se, por essa via, muito acima de um mero conjunto de procedimentos técnicos de ensino-aprendizagem.

Por outro lado, desta aparente antinomia ressalta a impressão de que pedagogia e pedagogy talvez não tenham significados tão próximos como aparentam, porque não creio que haja lugar a dúvida sobre a idêntica vontade dos referidos autores de contribuírem para impulsionarem a educação em direção à mesma grande finalidade: servir de caminho por onde se chega à plena cidadania, através da conscientização, da individualidade dialogante, da autonomia e da criatividade, o que implica sempre a redefinição dos papéis de todos, educandos e educadores.

Para uma discussão sobre a questão da pedagogia, da inovação e do papel que devem ter nos estudos curriculares, este dossiê agrupa nove artigos assinados por autores que desenvolvem o essencial da sua atividade nas duas margens do grande rio atlântico, no Brasil e em Portugal. Os artigos vão surgindo de acordo com as suas características, começando pelos que são de natureza mais conceptual e terminando com os que abordam exemplos ou propostas mais específicas, sem deixarem de ser perpassados pela reflexão imprescindível.

São eles:

Discutindo conceitos em torno do Currículo, de Jesus Maria SOUSA;

Matética, pedagogia e o papel que ainda não têm nos estudos curriculares, de Carlos Nogueira FINO; 
Que inovação a pedagogia queer propõe ao currículo escolar?, de Alfrancio Ferreira DIAS e Carlos André Araújo MENEZES;

Da inovação pedagógica e do papel da tecnologia na educação: algumas considerações possíveis no quadro do Projeto Gilgamesh, de Lia Raquel OLIVEIRA;

Lost in translation? Professores, tecnologias e inovação na sala de aula, de Geovana Lunardi MENDES:

Descongelar a pedagogia: a introdução de novas medidas educativas em Portugal, de Helena KOVACS e Luís TINOCA:

Novas Tecnologias e Comunicação Escola-Pais: implicações para uma escola democrática e interface com o currículo oculto, de Fernanda MARTINS;

Ambientes educativos inovadores: o estudo do fator espaço nas 'salas de aula do futuro' portuguesas, de Neuza PEDRO;

A Aprendizagem Colaborativa através da rede: limites e possibilidades, de Fernando CORREIA.

Desejo ao leitor uma leitura instigadora e proveitosa.

\section{Referências}

FREIRE, P. Pedagogia do Oprimido [49a Reimpressão]. Rio de Janeiro: Paz e Terra, 2010.

PINAR, W. F. The Problem with Curriculum and Pedagogy. Journal of Curriculum and Pedagogy Vol. 2 , Iss. 1, 2005. 
| 13

Número Temático:

Pedagogia, inovação pedagógica e o papel que devem ter nos estudos curriculares 
